\title{
Prevalence of Urinary Schistosomiasis Among Primary School Pupils
}

\author{
Faith Feranmi Folahan ${ }^{1}$, Luke Ekundayo Edungbola ${ }^{1}$, Joy Temiloluwa Folahan ${ }^{2}$ \\ ${ }^{7}$ Department of Medical Microbiology and Parasitology, Faculty of Basic Medical Sciences, College of Health Sciences, \\ University of Ilorin, Ilorin, Nigeria \\ ${ }^{2}$ Department of Pharmacology \& Therapeutics, Faculty of Basic Medical Sciences, College of Health Sciences, University \\ of Ilorin, Ilorin, Nigeria
}

\begin{abstract}
Objectives: Schistosomiasis is a chronic, progressive and granulomatous disease which is not immediately fatal but constitutes enormous medical and public health implications. This study was carried out to determine the prevalence, intensity, Knowledge, Attitude and Practice of urinary schistosomiasis among primary school pupils (aged 4-16 years) in Owena town, Ondo State, Nigeria.

Methods: Urine specimens were collected and examined, using a 325 Wire Mesh filter and microscopy. The conclusive diagnosis was based on the presence of the characteristic eggs of Schistosoma haematobium, while the intensity of infection was described as the number of eggs per $10 \mathrm{ml}$ of urine (eggs/10ml). 464 school children, comprising 268 (57.8\%) boys and 196 (42.2\%) girls, were examined.
\end{abstract}

Results: Altogether, 175 (37.7\%) of the pupils examined had the characteristic egg of S. haematobium in their urine. Boys, (42.3\%), were significantly more infected than girls, $(31.6 \%)(p<0.05)$. The highest prevalence of infection $(47.2 \%)$ was seen among pupils in the age range of 8-10years while the lowest (28.0\%) occurred among 11-13years. Boys had significantly higher mean (SD) egg-count 428 (5.8) eggs/10 ml/SD and prevalence of macro-hematuria (70.2\%) than girls 373.0 (3.1) eggs/10ml/SD and $29.8 \%$ respectively] $(p<0.05)$. The relationship between water-contact activities and prevalence of infection was statistically significant $(x 2=24.17, p<0.05)$.

Conclusion: This study identified protracted water-contact activities, ignorance, and lack of safe water supply as the major risk factors promoting endemicity of $S$. haematobium in Owena town. It is therefore imperative that interventions and control measures, such as health education, safe water supply, and chemotherapy are implemented. J Microbiol Infect Dis 2021; 11(2):95-104.

Keywords: Urinary schistosomiasis, water-contact, Schistosoma haematobium, hematuria, egg-count

\section{INTRODUCTION}

Schistosomiasis is a major Neglected Tropical Disease (NTD) with 240 million people infected globally, and about 700 million are at risk [1]. It is acquired solely through direct contact with freshwater bodies that breed the snail intermediate host (Bulinus species), and which has been contaminated with schistosome eggs; which undergo polyembryony in the intermediate host, to produce infective cercariae.
Schistosomiasis is largely an occupational disease of farmers, fishermen, and workers of irrigation farms. Sub-Saharan Africa harbors over $90 \%$ of the estimated 240 million world cases of human schistosomiasis and records more than 200,000 schistosomiasis-associated deaths annually [2].

The disease is caused by digenetic trematodes belonging to the genus Schistosoma. The three major species of human schistosomes are Schistosoma haematobium (which causes

Correspondence: Dr. Faith Feranmi Folahan, Department of Medical Microbiology and Parasitology, Faculty of Basic Medical Sciences, College of Health Sciences, University of Ilorin, Ilorin, Nigeria 
urinary schistosomiasis); Schistosoma mansoni and Schistosoma japonicum (both causes intestinal schistosomiasis). The eggs of adult female schistosomes are predominantly responsible for pathogenicity in schistosomiasis [3], causing morbidity through ova deposition in and around various organs, resulting in inflammation, lesions, and pathological alteration of these organs.

In endemic regions like Nigeria, the majority of children present macroscopic hematuria, which is indicative of adverse pathological effects in the lower urinary tract, due to persistent exposure and re-infection. Untreated long-period infections lead to the formation of polyps, hypertrophic nodules, and egg deposition, which could result in granulomas, fibrosis, and calcifications in the vesical wall [4]. As the children grow and age, vesicoureteral reflux and obstructive uropathy are very much likely to occur, causing them to suffer hydronephrosis, chronic bacteriuria, vesical cancer, and sometimes, renal insufficiency in their youth $[5,6,7]$.

Schistosomiasis-associated bladder cancer (usually squamous cell carcinoma), is a devastating aftermath of prolonged untreated urinary schistosomiasis, and it is dominant in endemic countries, prompting the International Agent for Research on Cancer (IARC) to classify S. haematobium alongside Opisthorchis viverrini and Clonorchis sinensis (all parasites) as group 1 definitive biological carcinogenic agents [8]. Most cases of aggressive urinary bladder cancers seen among young age groups in some parts of Africa were schistosomiasis-associated squamous cell carcinoma [7,9]. In other cases, fibrosis and calcification in the lower urinary tract often occur, leading to secondary infection, reflux, obstruction, and even stone formation [9]. Repeatedly infected school children also suffer from malnutrition, poor physical, cognitive, and psychosocial development $[10,11]$.

Nigeria has the highest prevalence of human schistosomiasis in Sub-Saharan Africa with about 62.3 million cases, which comprises over $26 \%$ of the world cases requiring treatment $[12,13]$. There is an increasingly high infection rate among school children [14], and about 3 million school-age children undergo treatment programs each year, but that's only $6 \%$ of the total infected children [13].
The World Health Assembly (WHA) had consistently made several resolutions, over the years, with the aim to achieve an effective and sustainable schistosomiasis control. Part of these resolutions includes scaling up drug development efforts, provision of safe water, an international collaboration of partners, etc. $[15,16]$. The implementation of these efforts in some countries has yielded positive and impressive results, however, the situation has remained stagnant in most countries in subSaharan Africa. The fact that Schistosomiasis is not immediately fatal was largely responsible for the neglect, whereas other diseases were treated with much concern. Nigeria only began implementing major control strategies in the early 2000s. The 2001 WHA 54.19 resolution [17] on attaining at least $75 \%$ regular treatment benchmark of all school-aged children for schistosomiasis and Soil-Transmitted Helminths (STH) in endemic communities by 2010 initiated serious political commitment in many member States, but a serious national action plan for the control of NTDs in Nigeria only came up a decade later [18]. The aim of the WHA resolution to achieve a significant reduction in schistosomiasis morbidity by 2010 became unachievable in Nigeria, and neither is it now, in 2021.

Nigeria, however, has intensified campaigns against schistosomiasis and other NTDs, using mass drug administration as a notable effort in the past years. This practice has helped to reduce morbidity in only a few areas, but it has not been adequate to reduce or stop transmission in the country. Beyond the government's intervention to curb schistosomiasis transmission, some nongovernmental organizations (NGOs) and partners, such as the Carter Centre Schistosomiasis Control Programme, the NTD NGO Network (NNN), etc. have carried out various control programs in different parts of Nigeria $[19,20]$. In spite of these collaborations lasting for decades, schistosomiasis remains a serious public health problem in Nigeria.

One of the major challenges of achieving control of schistosomiasis has to be the sole reliance on chemotherapy. Nigeria, like many other subSaharan African countries, has consistently depended on chemotherapy alone in the bid to control schistosomiasis, whereas it is supposed 
to be an integral part of an integrated approach, as it is being done in other countries. In addition, insurgency and insecurity have also contributed, in part, to the non-realization of the control of schistosomiasis in Nigeria. Recently, the COVID-19 pandemic may have also impeded interventional programs and activities on many diseases, schistosomiasis inclusive.

Despite strengthening her efforts to reduce schistosomiasis transmission and morbidity in recent times, epidemiological evidence still suggests that Nigeria is far behind in achieving sustainable control. Collaborations with international partners and Non-governmental organizations are very much needed in safe water supply and in the provision of infrastructures for personal and public health hygiene. Likewise, the development of an integrated approach for community-based implementation of strategies such as thorough survey and collation of epidemiological data, adoption of a uniform methodology for comparable data, and inclusive data collection involving previously neglected endemic rural areas are very essential in achieving positive and sustainable results in schistosomiasis control in Nigeria.

Hence, this study was carried out in Owena town to determine the prevalence, intensity, and predisposing factors of urinary schistosomiasis among school children, and to relate prevalence to various parameters. It is hoped that the findings of this study will assist public health authorities to identify and implement integrated and effective measures to control the prevalence and burden of schistosomiasis, significantly, in Owena town and the nation at large.

\section{METHODS}

\section{Ethical clearance}

This study was approved by the Ethical Review Committee of the College of Health Sciences, University of Ilorin, Nigeria. Permissions were also granted by the Local Government Primary Health Care Board and the Universal Basic Education Board at Idanre L.G.A., Ondo State. The community head, school heads, class teachers, Parents and Teachers' Association (PTA), and the pupils were properly informed about the nature, purpose, benefits, procedure of research, and their roles. Participation was made absolutely voluntary and free to opt-out.
However, participation was encouraged, based on the significance and relevance of the study. Infected pupils were not treated with Praziquantel during this study, as treatment is only permitted by registered medical personnel. However, details of disease burden and the need for prompt MDA were submitted alongside the study report, to the primary health care board for appropriate actions.

\section{Study Design}

A cross-sectional school-based study was carried out among school children aged 4-16 years in Owena town of Ondo State, Nigeria. Data were collected over a period of five months from December 2018 to April 2019, in three randomly selected primary schools - Our Saviour Primary School, St. Theresa Primary School, and L.A. Primary School. Participants were assigned unique reference codes that represent the school, class, and serial number.

\section{Study Area}

Owena town is the headquarters of Idanre Local Government Areas of Ondo State, Nigeria, with a distance of about $294 \mathrm{~km}$ from Lagos and $453 \mathrm{~km}$ from Abuja (Figure 1). Residents of Owena town are mostly farmers with very few fishermen, traders, and civil servants. They rely mostly on Owena River, directly or indirectly, for daily and domestic needs.

\section{Study Population}

Primary school pupils were deliberately targeted for this study because they are the most vulnerable to infection, disease complications, and dissemination of infection. In addition, they are a representation of families in the community, readily available and easily accessible through their schools. The sample size was calculated using the formula $\left(n=z^{2} * p\right.$ * $\left.(1-p) / e^{2}\right)$ for the qualitative variable. A random sampling technique was used to select the primary schools in the study area. To eliminate bias, we attempted to enroll all available children $\leq 16$ years of age from the selected primary schools as long as consent is given. Overall, 464 children ( $57.8 \%$ boys and $42.2 \%$ girls) were included in this study and asked to complete the questionnaire.

\section{Questionnaire Survey}


A standardized questionnaire (which has been tested previously with a population of the same age, socio-cultural background, and exposure), was administered by the class teachers who were trained on how to obtain and record data of each pupil, including their demographic status, duration of stay in the community, personal hygiene, knowledge about schistosomiasis, etc. In addition, participants underwent physical examinations to record anthropometric details of weight and height.

\section{Urine specimen collection and examination}

Urine specimens were collected between 11:00 14:00 hours, with the assistance of the class teachers. Pupils were first asked to run a distance of about 200 yards to stimulate urine production before receiving wide-mouth transparent, disposable, plastic cups for urine collection. $10 \mathrm{ml}$ of $70 \%$ Alcohol was dispensed into universal bottles, using a $10 \mathrm{ml}$ syringe as a standard procedure. Thereafter, $10 \mathrm{ml}$ of urine was drawn from the plastic cups submitted by each pupil, using a $10 \mathrm{ml}$ disposable syringe, and dispensed into a universal specimen bottle containing $10 \mathrm{ml}$ of $70 \%$ alcohol, for preservation.

The universal bottle for each pupil was properly labeled with coded identification by school, class, and serial number, using masking tape and permanent markers. The collected specimens were then stored in strong paper cartons and sellotaped to prevent spills or displacement during transportation to the Laboratory.

\section{Specimen Examination}

Urine specimens were examined macroscopically for visible hematuria, volume, and turbidity. The intensity of visible hematuria was noted, recorded, and categorized as light $(+)$, moderate $(++)$, heavy $(+++)$, or nonhematuria (-). Parasitological examination of the preserved urine specimens was carried out using filtration technique with a 325 Wire Mesh as described by Edungbola et al. [21]. The urine specimen was allowed to filter through the Wire Mesh, which had been folded conically and placed in a small plastic funnel on an empty beaker or flask. The residue was washed into a cross-hatched Petri dish for examination under a dissecting microscope at X20 magnification for characteristic eggs of Schistosoma hematobium and then counted, using a hand tally counter. The intensity of infection was expressed as a number of eggs per $10 \mathrm{ml}$ of urine. For quality control and accuracy, eggs were counted by the two researchers consecutively.

The data obtained were analyzed using the Statistical Package for Social Sciences (SPSS) application version 20. The prevalence and intensity of the disease, as well as parameters obtained from the questionnaires were analyzed. Chi-square test was used to compare the parameters and determine the degree of associations between observed variables at 95\% confidence interval.

\section{RESULTS}

A total of 464 Pupils were examined in this study, $268(57.8 \%)$ boys and $196(42.2 \%)$ girls, between ages $4-16$ years. Other demographic details are outlined in Table 1.

The overall prevalence of urinary schistosomiasis among the pupils was $37.7 \%$. Infection was significantly higher among boys $(42.3 \%)$ than girls $(31.6 \%), \quad(p=.0207)$. The highest prevalence of infection (46.7\%) was observed among the age group 8-10 years while the lowest $(28.0 \%)$ was among the age group $11-13 y r s(p=0.0016)$. There was a significant relationship between water-contact activity and prevalence of infection, as swimming in a river had a significantly higher prevalence (56.2\%) than other activities. (Table 2).

The intensity of infection was determined by classifying egg counts into ranges from 1-500 eggs $/ 10 \mathrm{ml}, 501-1000$ eggs $/ 10 \mathrm{ml}$, and $>1000$ eggs/10 $\mathrm{ml}$, representing low, moderate, and heavy intensities respectively. Of the 175 positive urine specimens, 117 (66.9\%) had a low intensity of infection, $42(24.0 \%)$ were moderate and $16(9.14 \%)$ had a heavy intensity of infection (Table 3). The mean (SD) egg-count was also significantly higher among boys 428.0 (5.0) eggs/10 $\mathrm{ml}$ than girls 373.0 (3.1) eggs/10 $\mathrm{ml}(\mathrm{p}<0.05)$.

A total of 104 (22.4\%) from the 464 pupils examined exhibited visible hematuria, which was significantly related to the prevalence of infection $(p<.05)$. The age group 8-10 years had the highest prevalence of macrohematuria (27.5\%) (Figure 2). The intensity of hematuria was graded as light, moderate and heavy based on 
physical examinations, and of the 104 hematuria, $74(71.2 \%)$ had light intensity, 26 $(25 \%)$ were moderate and $4(3.8 \%)$ had heavy intensity (Table 4). The relationship between infection and intensities of hematuria is illustrated in Figure 3.

In respect to anthropometric measurements, there was no statistical difference between the mean weight and height of infected pupils and their non-infected counterparts $(p>0.05)$.

\section{DISCUSSION}

The overall prevalence of urinary schistosomiasis (37.7\%) established in this study suggests that Owena town in Idanre L.G.A. of Ondo State is endemic for Urinary Schistosomiasis [22], i.e about one-third of the pupils are infected with urinary schistosomiasis. This is also similar to the findings from other parts of Nigeria [23,24] and Africa [25,26].

Ignorance and the proximity of the community to Owena River were identified as the major factors possibly responsible for the endemicity of urinary schistosomiasis in the study area. The river creates a suitable ecology for the transmission and spread of schistosomiasis while the nearness of the community to the river increases the frequency of water contact. Another factor is the participation of school pupils in water-related occupations with their parents, such as irrigation farming and sometimes fishing.

In this study, boys were significantly more infected than girls and, the infected boys had a higher mean egg count than infected girls. This high rate of infection among boys could be attributed to boys being less restricted, physically stronger, and more adventurous than girls. They indulge in water-related activities such as swimming, bathing in rivers, and irrigation farming more than girls. Moreover, factors such as the development of secondary sexual characters, socio-cultural practices and religious believe restrict female children from swimming or bathing openly in the cercariainfested streams and rivers.

Significant association of urinary schistosomiasis with gender had been reported across Nigeria [27-29]. Although Ejima and Odaibo [30] reported higher infection among girls, Nnoruka et al [31] suggested that there is no consistent pattern attributable to sex differences with respect to infection in Nigeria. However, these variations are likely to be associated with the methodology used, the environment, demographic factors, and the degree of exposure to water bodies due to cultural, social, and behavioral factors.

In this study, pupils under 10 years of age were more infected than those above 10 years, with the age group 8-10 years more infected than others. High intensities of infection among pupils in their first decade had also been reported in various parts of Nigeria [32-34] and Africa [26].

Table 1. The demographic and socioeconomic characteristics of the participants $(n=464)$.

\begin{tabular}{|c|c|c|}
\hline Characteristics & $\mathrm{n}$ & $\%$ \\
\hline \multicolumn{3}{|l|}{ Gender } \\
\hline Males & 268 & 57.80 \\
\hline Females & 196 & 42.20 \\
\hline \multicolumn{3}{|l|}{ Age groups } \\
\hline$\leq 4$ years & 5 & 1.08 \\
\hline 5-7 years & 57 & 12.29 \\
\hline $8-10$ years & 182 & 39.22 \\
\hline $11-13$ years & 182 & 39.22 \\
\hline $\begin{array}{l}\text { 14-16 years } \\
\text { Schools of Pupils }\end{array}$ & 38 & 8.19 \\
\hline L.A. Primary School & 216 & 46.60 \\
\hline St. Theresa Primary School & 163 & 35.10 \\
\hline Our Saviour Primary School & 85 & 18.30 \\
\hline \multicolumn{3}{|l|}{$\begin{array}{l}\text { Source of water for domestic } \\
\text { purposes }\end{array}$} \\
\hline Owena River & 428 & 92.24 \\
\hline Public Water Supply & 27 & 5.82 \\
\hline In-house Water Supply & 9 & 1.94 \\
\hline \multicolumn{3}{|l|}{ Fathers' Occupation } \\
\hline Farming & 343 & 73.92 \\
\hline Trading & 41 & 8.84 \\
\hline Artisans & 39 & 8.40 \\
\hline Civil Servant & 16 & 3.45 \\
\hline Commercial Bus Driver & 25 & 5.39 \\
\hline \multicolumn{3}{|l|}{ Water Contact Activities } \\
\hline Swimming in the river & 162 & 34.91 \\
\hline Bathing (at the river bank) & 27 & 5.82 \\
\hline Farming & 25 & 5.39 \\
\hline Fetching of Water & 119 & 25.65 \\
\hline Washing clothes & 95 & 20.47 \\
\hline
\end{tabular}




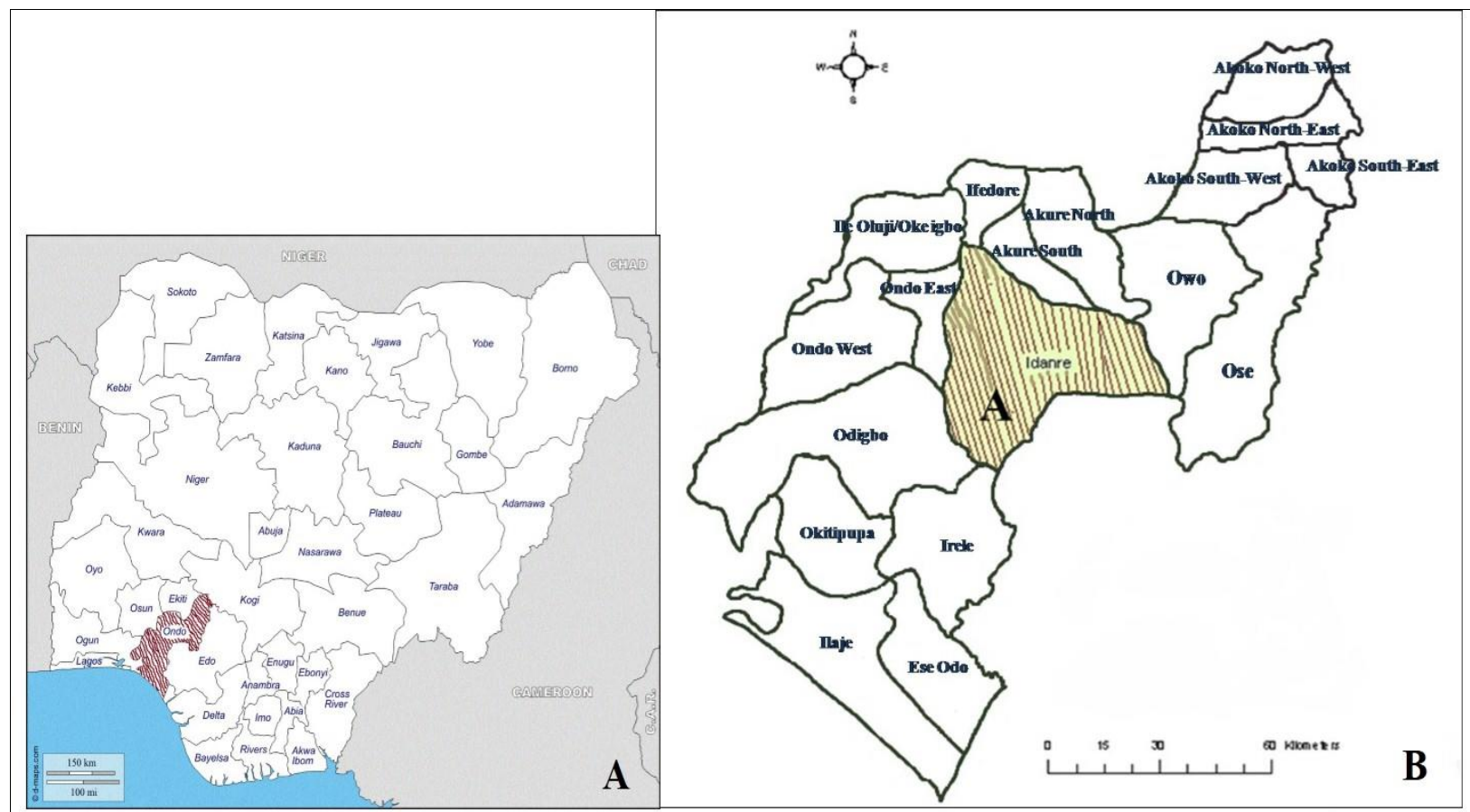

Figure 1: A - The Map of Nigeria, showing Ondo State (shaded) B - The Map of Ondo State, showing Idanre Local Govt. Area (shaded A)

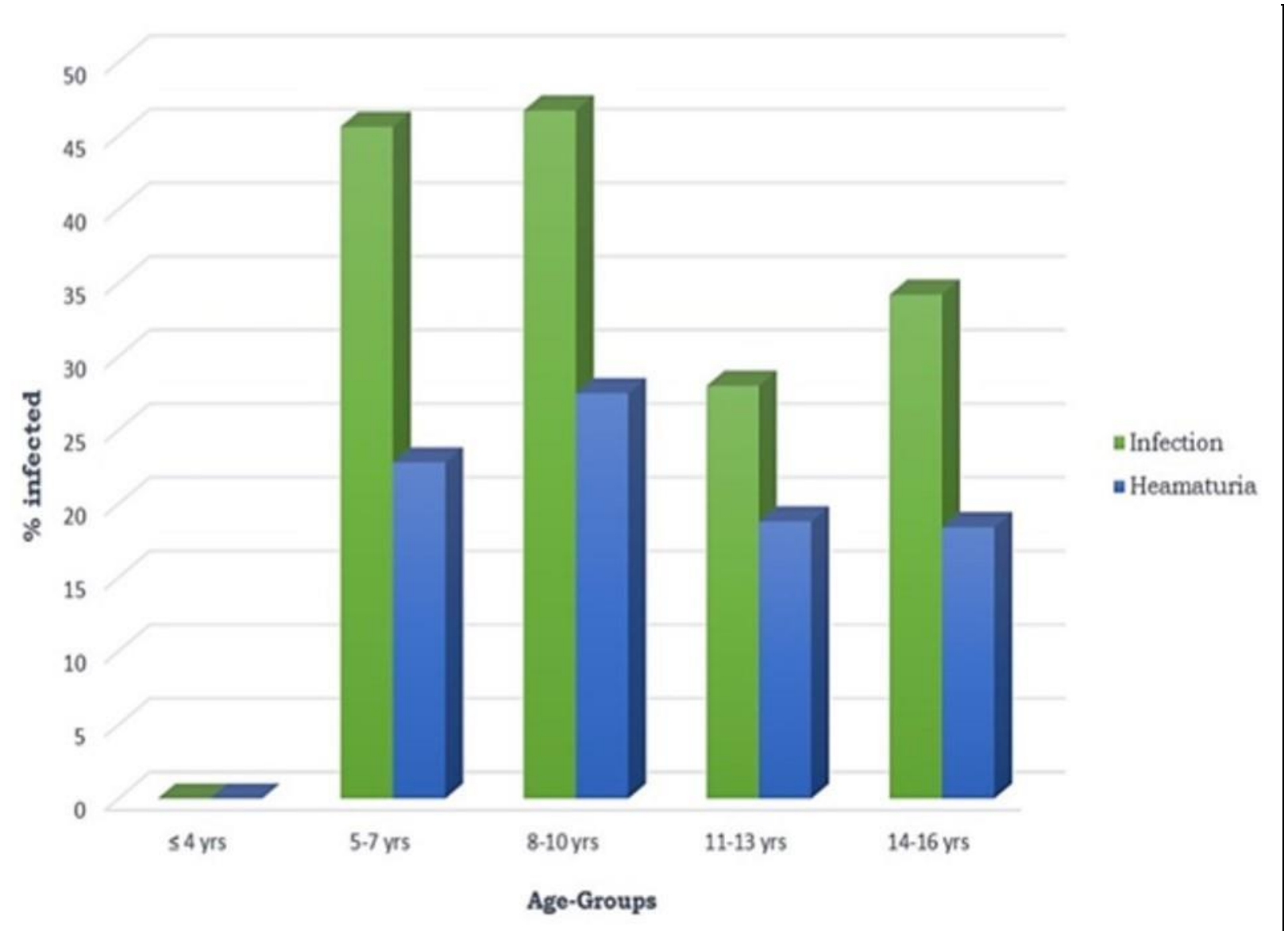

Figure 2. Relationship between infection and visible hematuria. 
Table 2. Prevalence of Urinary Schistosomiasis by various parameters ( $N=464)$

\begin{tabular}{|c|c|c|c|c|}
\hline Parameters & & No (\%) examined & No (\%) infected & P Value \\
\hline \multirow{3}{*}{ Gender } & Male & $268(57.8)$ & $113(42.3)$ & \multirow{3}{*}{$p=0.02$} \\
\hline & Female & $196(42.2)$ & $62(31.6)$ & \\
\hline & Overall & $464(100)$ & $175(37.7)$ & \\
\hline \multirow{6}{*}{ Age } & $\leq 4$ years & $5(1.07)$ & $0(0.0)$ & \multirow{6}{*}{$p=0.0016$} \\
\hline & $5-7$ years & $57(12.28)$ & $26(45.6)$ & \\
\hline & $8-10$ years & $182(39.22)$ & $85(46.7)$ & \\
\hline & $11-13$ years & $182(39.22)$ & $51(28.0)$ & \\
\hline & $14-16$ years & $38(8.19)$ & $13(34.2)$ & \\
\hline & Overall & $464(100)$ & $175(37.7)$ & \\
\hline \multirow{4}{*}{ Schools } & L.A. Primary School & $216(46.6)$ & $90(41.7)$ & \multirow{8}{*}{$\mathrm{p}=0.21$} \\
\hline & St. Theresa Primary School & $163(35.1)$ & $67(41.1)$ & \\
\hline & Our Saviour Primary School & $85(18.3)$ & $18(21.2)$ & \\
\hline & Overall & $464(100)$ & $175(37.7)$ & \\
\hline \multirow{4}{*}{ Source of water for domestic use } & Owena River & $428(92.24)$ & $168(39.25)$ & \\
\hline & Public Water Supply & $27(5.82)$ & $6(22.22)$ & \\
\hline & In-house Water Supply & $9(1.94)$ & $1(11.11)$ & \\
\hline & Overall & $464(100)$ & $175(37.7)$ & \\
\hline \multirow{6}{*}{ Father's Occupation } & Farming & $343(73.92)$ & $130(37.9)$ & \multirow{6}{*}{$p=0.86$} \\
\hline & Trading & $41(8.84)$ & $12(29.3)$ & \\
\hline & Artisans & $39(8.40)$ & $18(46.2)$ & \\
\hline & Commercial Bus Driver & $25(5.37)$ & $10(40.0)$ & \\
\hline & Civil Servant & $16(3.45)$ & $5(31.3)$ & \\
\hline & Overall & $464(100)$ & $175(37.7)$ & \\
\hline \multirow{6}{*}{ Water Contact Activities } & Swimming at the river & $162(34.91)$ & $91(56.2)$ & \multirow{6}{*}{$p<0.05$} \\
\hline & Fetching of Water & $130(28.01)$ & $46(35.38)$ & \\
\hline & Washing of Clothes & $120(25.86)$ & $18(15.0)$ & \\
\hline & Bathing (at the river bank) & $27(5.82)$ & $12(44.4)$ & \\
\hline & For Farming & $25(5.39)$ & $8(32.0)$ & \\
\hline & Overall & $464(100)$ & $175(37.7)$ & \\
\hline
\end{tabular}




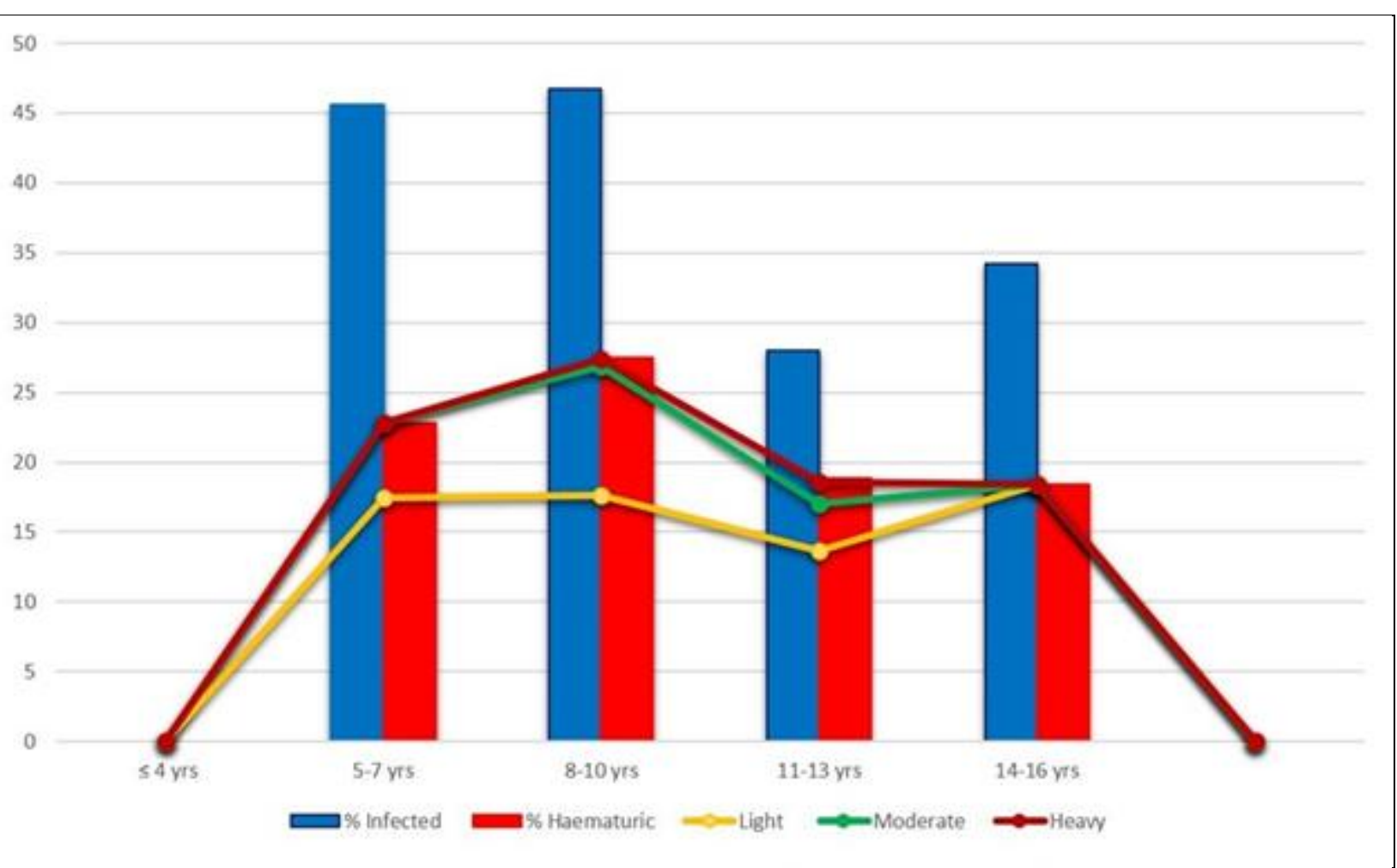

Figure 3. Relationship between infection and intensities of visible hematuria.

Table 3. Intensity of Infection by Age Groups ( $N=464)$

\begin{tabular}{|c|c|c|c|c|c|c|}
\hline \multirow[b]{2}{*}{$\begin{array}{l}\text { Age } \\
\text { Group }\end{array}$} & \multirow[b]{2}{*}{$\begin{array}{l}\text { Number } \\
\text { Examined }\end{array}$} & \multirow[b]{2}{*}{$\begin{array}{l}\text { No. Infected } \\
(\%)\end{array}$} & \multicolumn{3}{|c|}{ Range of Egg Count (Eggs/10 ml of Urine) } & \multirow[b]{2}{*}{$\begin{array}{l}\text { Mean (SD) Egg-count } \\
(\text { Egg/10 ml urine/SD) }\end{array}$} \\
\hline & & & $\begin{array}{l}1-500 \\
\text { (Light) }\end{array}$ & $\begin{array}{c}501-1000 \\
\text { (Moderate) }\end{array}$ & $\begin{array}{l}>1000 \\
(\text { Heavy })\end{array}$ & \\
\hline$\leq 4 \mathrm{yrs}$ & 5 & $0(0.0)$ & $0(0.0)$ & $0(0.0)$ & $0(0.0)$ & 0.00 \\
\hline $5-7$ & 57 & $26(41.9)$ & $21(17.9)$ & $5(11.9)$ & $0(0.0)$ & $691.4(2.6)$ \\
\hline $8-10$ & 182 & $85(46.7)$ & $50(42.7)$ & $23(54.8)$ & $12(75.0)$ & $1013.2(3.0)$ \\
\hline $11-13$ & 182 & $51(28.0)$ & $35(29.9)$ & $12(28.6)$ & $4(25.0)$ & $888.5(2.0)$ \\
\hline $14-16$ & 38 & $13(34.2)$ & $11(9.40)$ & $2(4.80)$ & $0(0.0)$ & $612.1(12.8)$ \\
\hline Total & 464 & $175(37.7)$ & $117(66.9)$ & $42(24.0)$ & $16(9.14)$ & $801.0(2.1)$ \\
\hline
\end{tabular}

Table 4. Intensity of hematuria by age-group $(\mathrm{N}=464)$.

\begin{tabular}{lcccccc}
\hline $\begin{array}{l}\text { Age group } \\
\text { Years) }\end{array}$ & No. Examined & No. (\%) & \multicolumn{2}{c}{ No. (\%) with } & \multicolumn{2}{c}{ No. (\%) with hematuria by intensity } \\
infected & Hematuria & Light & Moderate & Heavy \\
\hline$\leq 4$ yrs & 5 & $0(0.0)$ & $0(0.0)$ & $0(0.0)$ & $0(0.0)$ & $0(0.0)$ \\
$5-7$ & 57 & $26(45.6)$ & $13(22.8)$ & $10(17.5)$ & $3(5.3)$ & $0(0.00)$ \\
$8-10$ & 182 & $85(46.7)$ & $50(27.5)$ & $32(17.6)$ & $17(9.3)$ & $1(0.5)$ \\
$11-13$ & 182 & $51(28.0)$ & $34(18.8)$ & $25(13.7)$ & $6(3.3)$ & $3(1.6)$ \\
$14-16$ & 38 & $13(34.2)$ & $7(18.4)$ & $7(18.4)$ & $0(0.00)$ & $0(0.00)$ \\
Total & 464 & $175(37.7)$ & $104(22.4)$ & $74(16.0)$ & $26(5.6)$ & $4(0.9)$ \\
\hline
\end{tabular}


The high infection rate among this group reveals that children in the community are exposed to infection very early in their lives while the high intensity of infection can be attributed to repeated exposure to infested freshwater bodies as well as their desire to constantly participate in water-contact activities more than the older age groups, who find recreation in other activities more appealing.

Pupils who admitted to swimming in the river had the highest infection amongst other watercontact activities. Protracted water-contact activities, such as swimming, allow the penetration of infectious cercaria into a human host. Swimming was practiced more than other activities among the pupils and became the major form of transmission.

About $46.3 \%$ of the infected pupils manifested visible hematuria of different intensities. Hematuria is a suggestive indication for urinary schistosomiasis and has been ascribed to the pathological alterations induced by the egg of $S$. haematobium in the venous plexus of the bladder [11]. If untreated, chronic blood loss through hematuria may lead to serious medical conditions in infected children.

Conclusion: The endemicity of urinary schistosomiasis in Owena calls for intervention measures such as health education, periodic chemotherapy, provision and use of safe water, personal and public hygiene, and the control of transmission at various foci. Adequate health education, in form of Information Education and Communication (I.E.C) materials to intimate the pupils and public with the mode of transmission and prevention methods of the disease, is the recommended option to prevent further transmissions in a setting like this.

\section{ACKNOWLEDGMENTS}

We sincerely appreciate all the School Head Teachers, Class Teachers and school pupils. We appreciate the efforts of Mr. N. Fayose (Director) and Mr. J. Komolafe (Education Secretary) of the State Universal Basic Education Board (SUBEB) in Owena. Their timely support and interventions before, during and after specimen collection was seriously helpful in the success of this project.

Declaration of Conflicting Interests: The authors declare that they have no conflict of interest.
Funding: Not applicable.

\section{REFERENCES}

1. Brunn B, Aagaard-Hansen J. The social context of schistosomiasis and its control: An introduction and annotated bibliography. $1^{\text {st }}$ Edition. Geneva: World Health Organization 2008: 2

2. Hotez PJ, Kamath A Neglected Tropical Diseases in Sub-Saharan Africa: Review of their prevalence, distribution, and disease burden. PLoS Negl Trop Dis, 2009; 3 (8): 412.

3. Edungbola LD, Schiller EL. Histopthology of Hepatic and Pulmonary Granulomata Experimentally Induced with Eggs of Schistosoma mansoni in Mice. J Parasitol 1979; 65: 253-261.

4. Barsoum RS, Esmat G, El-Baz T. Human Schistosomiasis: Clinical Perspective: Review. Int J Adv Res Sci Eng Technol 2013; 4(5): 433-444.

5. Nokes C, Grantham-McGregor SM, Sawyer AW, Cooper ES, Bundy DAP. Parasitic Helminth Infection and Cognitive Function in School Children. Proceedings of the Royal Society of Biological sciences, 1992; 247 (1319): 1098.

6. Khalaf I, Shokeir A, Shalaby M. Urologic complications of genitourinary schistosomiasis. World J Urol 2012; 30(1):31-38.

7. Badmos KB, Popoola AA, Buhari MO, Abdulkadir AY. Ureteric schistosomiasis with obstructive uropathy. J Coll Physicians Surg Pak. 2009; 19(7):456-8.

8. International Agency for Research on Cancer (IARC). Monographs on The Identification of Carcinogenic Hazards to Humans: List of Classifications - Agents classified by the IARC Monographs, Volumes 1-128. https://monographs.iarc.who.int/list-of-classifications/

9. Neal PM. Schistosomiasis--an unusual cause of ureteral obstruction: a case history and perspective. Clin Med Res 2004; 2(4):216-227.

10. King $\mathrm{CH}$. The Causes and Impacts of Neglected Tropical and Zoonotic Diseases: Opportunities for Integrated Intervention Strategies. A12Schistosomiasis: challenges and opportunities. The National Academies: US Institute of Medicine Forum on Microbial Threat 2011; ISBN-13: 978-0-309-186346.

11. Burton JB, Clint EC, Thomas NO. Human Parasitology, $4^{\text {th }}$ Edition. Academic Press, Elsevier: USA, 2013; pp 197-209.

12. World Health Organization. Schistosomiasis: Number of people treated in 2010 Weekly Epidemiological Record 2010; 87(4):37-44.

13. Isabel Jones. Nigeria: Schistosomiasis, Stanford University, Up Stream Alliance, 2015; https://schito.staford.edu $>$ pdf $>$ Nigeria Accessed 10th March, 2018. 
14. DeSilva NR., Brooker S, Hotez, PJ., Montresor A, Engels D, Savioli L. Soil-transmitted Helminth Infections: Updating the Global Picture 2003; Trends Parasitol 19. 547-551.

15. World Health Organization (WHO). World Health Assembly Resolution (WHA) 28.53 Schistosomiasis. Geneva (1975)

16. World Health Organization (WHO). World Health Assembly Resolution WHA 29.58 Schistosomiasis. Geneva

www.who.int/entity/neglected diseases/mediacentre/ WHA_29.58_Eng.pdf?ua=1 (Accessed 08/02/2021).

17. Nigeria Master Plan for Neglected Tropical Diseases - 2013-2017. 2012; p. 142

18. World Health Organization (WHO). World Health Assembly Resolution WHA 54.19 Elimination of Schistosomiasis.

www.who.int/entity/neglected_diseases/mediacentre/ WHA_54.19_Eng.pdf?ua=1 (Accessed 13/02/2021)

19. Oyetunde TO, Wander deJesus J, Rafaella FQG. Schistosomiasis in Nigeria: Gleaning from the past to improve current efforts towards control, One Health, 2020; 11: 100183. ISSN 2352-7714, doi.org/10.1016/j.onehlt.2020.100183.

20. Carter Center Global Health Efforts - Nigeria Schistosomiasis Control. http://www.cartercenter.org/countries/nigeria-healthschistosomiasis.html

21. Edungbola LD, Asaolu SO, Omonisi MK, Aiyedun BA. Schistosoma haematobium infection among school children in the Babana District, Kwara State, Nigeria, Nigeria. Afr J Med Sci 1988; 17: 187-193.

22. World Health Organization. Prevention and control of Schistosomiasis and soil transmitted helminthiasis. W.H.O. Technical report. Series No. 912: i-vi. Geneva: World Health Org, 2002; 64pp.

23. Akeh AM, Ejezie GC, Enyi-Idoh KH, Eja ME, Agba $\mathrm{AO}$, Ogbeche JO. Urinary schistosomiasis, perceptions and treatment seeking behaviour in Sankwala, Cross-River State, Southeastern Nigeria. Nig J Parasitol 2010; 31: 7-13.

24. Houmsou SR. Profile of a one year epidemiological study of urinary schistosomiasis in two local government areas (L.G.As) of Benue State. Nig J Biomed Sci 2012; 1. 2:2

25. Sama MT Oyono E. Ratard RC. High risk behaviours and schistosomiasis infection in Kumba, Southwest Province, Cameroon. Intl J Environ Res Pub Health 2007; 4: 101-105.

26. Rasoamanamihaja CF, Rahetilahy AM, Ranjatoarivony B and et al. Baseline Prevalence and intensity of schistosomiasis at sentinel sites in Madagascar: Informing a national control Strategy. Parasit Vectors 2016; 9:50. 5-7.

27. Otuneme OG, Akinkuade FO, Obebe OO, et al. A study on the prevalence of Schistosoma haematobium and Schistosoma intercalatum in a rural community of Ogun State, Nigeria. South East Asia J Public Health, 2014; 4(1):67-71.

28. Raji H, Omenesa HO, Bishop HG. Prevalence of urinary schistosomiasis among pupils attending primary schools in Bomo village, Zaria-Nigeria. Intl $\mathrm{J}$ Res Eng Sci (IJRES), 2015; 3:14-19.

29. Nyamngee A, Yusuf KA, Edungbola LD, Akanbi II $A A$, Njaan AA, Olubiyi SK. Evidences of endemic Schistosoma haematobium infection among School Children in Shonga Community, Edu Local Government Area, Kwara State, Nigeria. Trop J Health Sci 2018; 25 (1): 14-20.

30. Ejima IA, Odaibo AB. Urinary schistosomiasis among school children in Abuja Local Government Area of Kogi State, Nigeria. J Sci Res 2007; 7: 30-35.

31. Nnoruka VC, Anya AO, Okafor FC. Epidemiological study on urinary schistosomiasis in Imo State II: Parasitological and morbidity studies among primary school children. Nig J Parasitol 2000; 23:111-118.

32. Ogbeide O, Okojie O, Wagbastoma V, Isah E. Schistosoma haematobium in rural school children in Nigeria. W Afri J Med 199413 (1): 31-33.

33. Mafiana CF, Ekpo UF, Ojo DA. Urinary schistosomiasis in Preschool children in settlements around Oyan reservoir in Ogun State, Nigeria: Implications for control. J Trop Med Int Health 2003; 8: 78-82.

34. Nwabueze AA, Opara KN. Outbreak of Urinary Schistosomiasis among School Children in Riverine Communities of Delta State, Nigeria: Impact of Road and Bridge Construction. J Med Sci 2007; 7 (4): 572 578. 